\title{
Absence of beta-tubulin gene mutation in gastric carcinoma
}

\author{
Naomi Urano ${ }^{1}$, Yoshiyuki Fujiwara ${ }^{1}$, Seitchi Hasegawa ${ }^{1,2}$, Yasuo Miyoshi ${ }^{2}$, Shinzaburo Noguchi ${ }^{2}$, \\ Shuj TAkiguchi ${ }^{1}$, Takushi Yasuda ${ }^{1},{\text { Masahiko } \text { YAno }^{1} \text {, and Morito Monden }}^{1}$ \\ ${ }^{1}$ Department of Surgery and Clinical Oncology, Graduate School of Medicine, Osaka University, 2-2, Yamadaoka (E-2), Suita, \\ Osaka 565-0871, Japan \\ ${ }^{2}$ Department of Surgical Oncology, Graduate School of Medicine, Osaka University, Osaka, Japan
}

\begin{abstract}
Background. Effective chemotherapy for advanced gastric cancer is yet to be established. Taxanes, novel anticancer drugs which bind to beta-tubulin and prevent disruption of microtubules, are newly approved and promising agents for advanced and recurrent gastric cancer. To predict the chemoresistance to a taxan in gastric cancer, we examined the genetic mutations of the beta-tubulin gene.

Methods. Fifty pairs of gastric tumor and normal mucosa tissues were obtained from operations and the genomic DNA was extracted from each specimen. The four exons of the betatubulin gene were amplified for DNA mutations by singlestrand conformation polymorphism (SSCP) methods and sequencing analysis.

Results. Nine (18\%) of 50 patients with gastric cancer had two kinds of silent variations of the beta-tubulin gene in exon 4. Three kinds of intronic variations were detected in exons 1, 2, and 3. However, no genetic alterations that would change the beta-tubulin protein structure were detected in any of the 50 gastric tumors.

Conclusion. Our findings indicate that mutations of the betatubulin gene, which might be a contraindication for chemotherapy based on taxans, were very rare events in gastric cancer.
\end{abstract}

Key words Beta-tubulin gene $\cdot$ Gastric cancer $\cdot$ SSCP $\cdot$ Gene mutation $\cdot$ Drug resistance

\section{Introduction}

Gastric carcinoma is one of the most lethal and frequent malignancies in Japan. Chemotherapy with a single anticancer agent or a combination of anticancer agents

Offprint requests to: Y. Fujiwara

Received: December 11, 2002 / Accepted: March 3, 2003 has been used for advanced or recurrent gastric carcinomas. However, the therapeutic effect of chemotherapy has been insufficient and unsatisfactory. Paclitaxel (Taxol; Bristol Myers Squibb, Princeton, NJ, USA), which was recently developed and approved for several kinds of human cancers, such as ovarian cancer, breast cancer, non-small cell lung cancer (NSCLC), and gastric cancer, might be a promising agent. The response rate of paclitaxel for gastric cancer was reported to be $28 \%$ as a single agent [1], and the response rate as second- or third-line chemotherapy was relatively high (20\% [2]).

Paclitaxel is a microtubule-disrupting agent and is thought to act by binding to beta-tubulin, which is a subunit of tubulin [3]. Paclitaxel induces microtubulin polymerization and inhibits depolymerization [4], which finally blocks the cell cycle in the metaphase $[5,6]$.

The beta-tubulin gene is localized in chromosome region 6p21.3 and includes four exons [7]. The deduced protein has 444 amino acids. The binding site of paclitaxel in beta-tubulin has been detected in the Nterminal 31 amino acids [8], which are encoded by exons 1 and 2 of the gene.

Schibler and Cabral [9] reported finding beta-tubulin gene mutations in paclitaxel-selected Chinese hamster ovary cells and in human small-cell lung cancer cells [10] which showed chemoresistance to paclitaxcel. Furthermore, Monzo et al. [11] reported that $16(33 \%)$ of 49 NSCLCs showed genetic mutations in the beta-tubulin gene, and none of the patients with beta-tubulin mutations had an objective response to paclitaxel.

These reports suggest that gene mutations of betatubulin may induce a change in microtubule dynamics and prevent paclitaxel from binding to the beta-tubulin molecule, which would result in resistance to the agent.

The purpose of this study was to examine the mutation status of the beta-tubulin gene in gastric cancer and to predict the chemoresistance, in patients with gastric cancer, to paclitaxcel, a promising antitumor agent. 


\section{Subjects, materials, and methods}

\section{Specimens and DNA extraction}

Fifty pairs of gastric tumor tissues and corresponding normal gastric mucosae were obtained from operations performed at the Department of Surgery and Clinical Oncology, Graduate School of Medicine, Osaka University. The specimens were dissected and stored at $-80^{\circ} \mathrm{C}$ until DNA extraction. Genomic DNAs were extracted from the frozen tissues by using Sepagene (TaKaRa and Sankou Junyaku, Tokyo Japan) according to the manufacturers' instructions. All specimens were collected after written informed consent was obtained from the patients.
Polymerase chain reaction (PCR)

The primer sets were designed to amplify the whole coding region of the beta-tubulin gene, including four exons (Fig. 1 and Table 1). As exon 4 is 1059 base pairs long, its entire length was amplified first, then divided into four regions which were amplified using nested PCR. The PCR reaction mixture contained $100 \mathrm{ng}$ of template DNA, $2 \mathrm{p}$-mol of each primer set, $0.5 \mathrm{U}$ of Taq polymerase (AmpliTaq Gold; Roche Molecular Systems, NJ, USA), and $2.5 \mathrm{mM} \mathrm{MgCl}$. The PCR cycling conditions were as follows: an initial denaturing step at $95^{\circ} \mathrm{C}$ for $10 \mathrm{~min}$, and 40 cycles at $95^{\circ} \mathrm{C}$ for $30 \mathrm{~s}$, $50^{\circ} \mathrm{C}-58^{\circ} \mathrm{C}$ for $30 \mathrm{~s}$, and $72{ }^{\circ} \mathrm{C}$ for $30 \mathrm{~s}$, followed by a final period of extension at $72^{\circ} \mathrm{C}$ for $5 \mathrm{~min}$. For
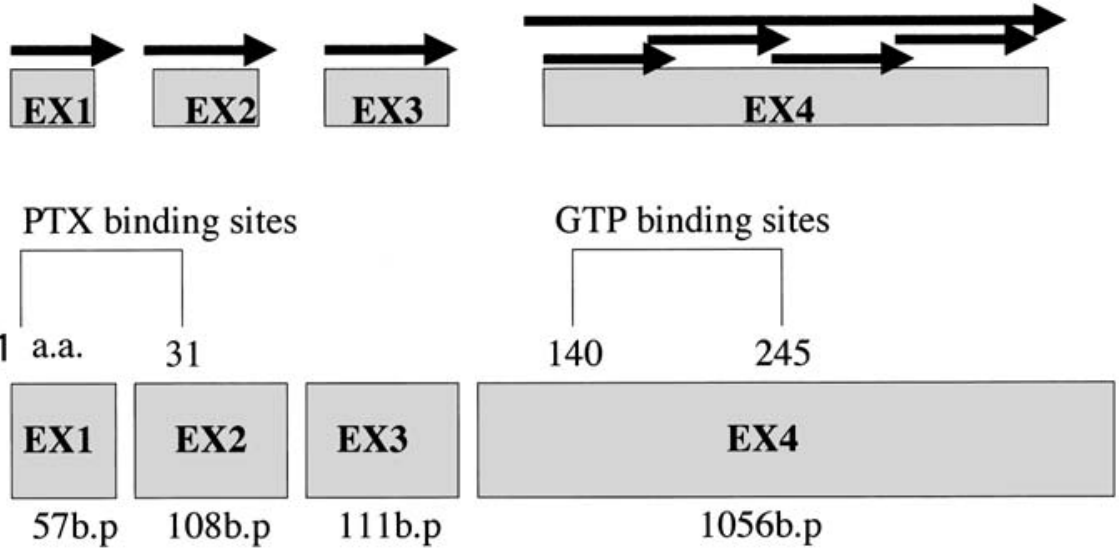

Fig. 1. Diagram of the beta-tubulin gene with exons $(E X)$ and analyzed regions indicated by arrows. The binding sites of paclitaxel $(P T X)$ and guanosine

1332 b.p. 444 amino acids chromosome 6p21.3 triphosphate $(G T P)$ are shown

Table 1. Beta-tubulin primers used for PCR, and annealing temperature for amplification

\begin{tabular}{|c|c|c|c|}
\hline Exon & Position & Sequence & $\begin{array}{c}\text { Annealing } \\
\text { temperature }\left({ }^{\circ} \mathrm{C}\right)\end{array}$ \\
\hline \multirow[t]{2}{*}{1} & Forward & AАCСТTCCAGCCTGCGACCTA & 55 \\
\hline & Reverse & TTCCCAGCTTTCCAAAGGCAAATG & \\
\hline \multirow[t]{2}{*}{2} & Forward & TAGTTGGGGACATAGTTGGC & 54 \\
\hline & Reverse & TAAGGCGTGCCCAGAAATGG & \\
\hline \multirow[t]{2}{*}{3} & Forward & AATGACAAGTCTCTGATCCC & 50 \\
\hline & Reverse & TCCAATACAACAATCATCTCC & \\
\hline \multirow[t]{2}{*}{4} & Forward & TGTATTGGAGTGCTAATACAG & 56 \\
\hline & Reverse & CTCCCTTGAAGCTGAGATGG & \\
\hline \multirow[t]{2}{*}{ - } & Forward & CATGTATCTTCCATACCCTG & 58 \\
\hline & Reverse & CTGAAGGTATTCATGATGCG & \\
\hline \multirow[t]{2}{*}{ - } & Forward & GAATGGGCACTCTCCTTATC & 58 \\
\hline & Reverse & GGACCATGTTGACTGCCAAC & \\
\hline \multirow[t]{2}{*}{ - } & Forward & ATGGAGTGTGTCACCACCTG & 58 \\
\hline & Reverse & GACTGCCATCTTGAGGCCAC & \\
\hline \multirow[t]{2}{*}{ - } & Forward & CCCAACAATGTCAAGACAGC & 58 \\
\hline & Reverse & CAAGATAGAGGCAGCAAACAC & \\
\hline
\end{tabular}

Each primer pair was designed in franking introns for amplification of each exon according to the beta-tubulin gene sequence (GenBank accession no. J00314) [15]. After the whole region of exon 4 was amplified, the four divided regions were amplified by the nested PCR primers shown PCR, polymerase chain reaction 
amplification of the whole region of exon 4 , the extension time was extended for $2 \mathrm{~min}$.

\section{Single-strand conformation polymorphism (SSCP) analysis}

SSCP analysis was performed using 5\% nondenaturing polyacrylamide gels (acrylamide/N,N-bisacrylamide 99:1) containing 10\% glycerol. After electrophoresis for $4.5 \mathrm{~h}$ at $850 \mathrm{~V}$, the gels were stained with SYBR Green II (TaKaRa, Otsu, Japan) and scanned with a fluorescence image analyzer (FM Bio Multi-View; TaKaRa).

\section{Sequence analysis}

The bands shifting on SSCP were cut out and amplified by PCR. PCR products were purified, and the sequence was analyzed using a Direct Sequence Kit (Big Dye Terminator version 3 Cycle Sequencing Ready Reaction Kit; Perkin-Elmer, MA, USA).

\section{Results and discussion}

The clinicopathological characteristics of the 50 patients whose tissues were examined in this study are listed in Table 2. None of the patients had had taxan-based che-

Table 2. Patients' clinicopathologic characteristics

\begin{tabular}{llr}
\hline Age (years) & $<50$ & 7 \\
& $50-70$ & 24 \\
Size of tumor (mm) & $>70$ & 10 \\
& $<20$ & 4 \\
& $20-49$ & 23 \\
Sex & $>50$ & 22 \\
& Male & 35 \\
Histology & Female & 15 \\
& Well-differentiated tubular adenocarcinoma & 5 \\
& Moderately differentiated tubular adenocarcinoma & 17 \\
Stage & Poorly differentiated tubular adenocarcinoma & 12 \\
& Signet-ring cell carcinoma & 6 \\
& IA & 13 \\
& IB & 7 \\
& II & 6 \\
& IIIA & 4 \\
& IIIB & 7 \\
& IV & 7
\end{tabular}

$\mathbf{a}$

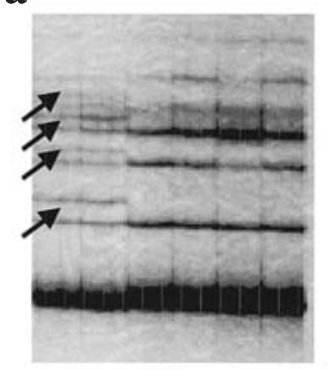

C

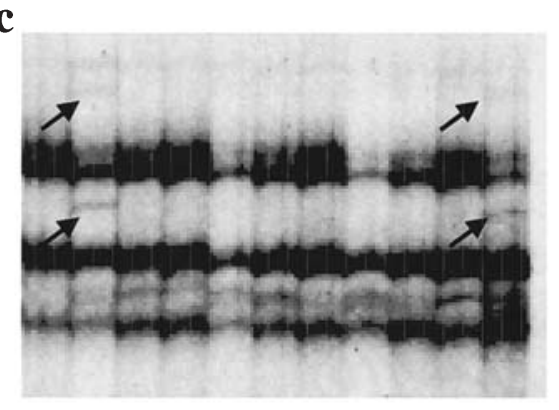

b

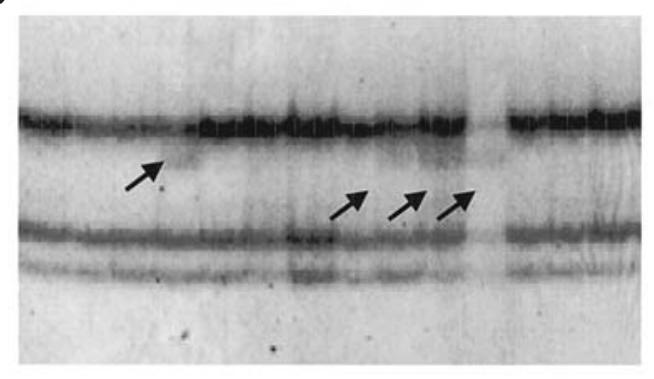

d

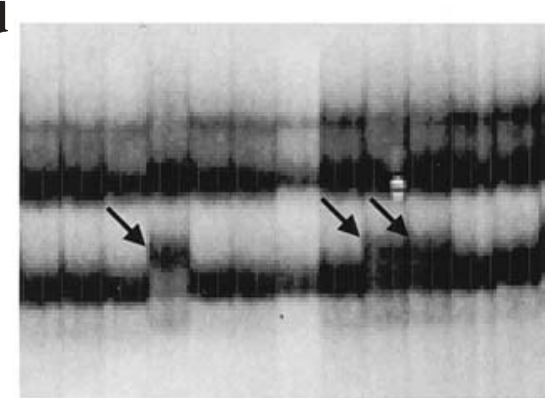

Fig. 2a-d. Single-strand conformation polymorphism (SSCP) analysis of the beta-tubulin gene. Arrows indicate the abnormally shifted bands. a Exon 1; b Exon 2; c Exon 3; d Exon 4 
motherapy. The SSCP analysis showed variant bands from exon 1 to exon 4 of the beta-tubulin gene (Fig. 2). The sequence analysis showed that 20 patients $(40 \%)$ had a nucleotide change in the intron at 85 base pairs downstream of exon 1 . Similarly, $4(8 \%)$ and $3(6 \%)$ patients, respectively, had a nucleotide change in the intron at 32 base pairs downstream of exon 2 and in the intron at 16 base pairs downstream of exon 3 . In exon 4 , 9 of the 50 tumors $(18 \%)$ had a sequence of CTA (Leu) and the remaining 41 showed CTG (Leu) at codon 217, and TGT $\rightarrow$ TGC (Cys) at codon 303 (Fig. 3, Table 3).

Taxanes, binding to beta-tubulin molecules, inhibit depolymerization, and induce an unusual polymerization and increase in the diameter of microtubules. Consequently, cell division is blocked and the cell cycle stops. Taxanes have a binding domain at the N-terminal region of beta-tubulin, which is coded by exons 1 and 2 of the gene. Several guanosine triphosphate (GTP) binding sites of beta-tubulin have been located in the region encoded by exon 4 [12]. Therefore, it is specu-

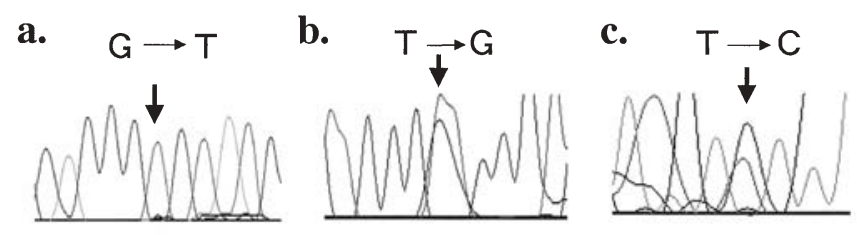

d.
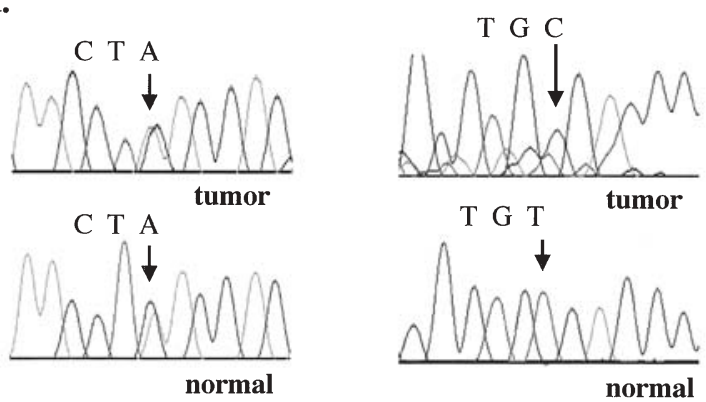

Fig. 3a-d. Sequencing analysis of polymerase chain reaction (PCR) products showing the shifted bands on SSCP analysis. Arrows indicate the location of nucleotide changes: $\mathbf{a}, \mathbf{b}$, and c in intron region downstream from exons 1,2 , and 3 ; $\mathbf{d}$ in exon 4 lated that if there are mutations in exon 1 or exon 2 of the beta-tubulin gene, paclitaxel cannot bind to beta-tubulin, and if the mutations exist in exon 4, GTP cannot promote microtubule assembly, and paclitaxelinduced abnormal polymerization may not occur $[6,13]$. Thus, beta-tubulin gene mutation may be associated with the resistance to taxanes.

Recently, beta-tubulin gene mutations have been identified in $33 \%$ of 49 patients with non-small cell lung cancer (NSCLC) given paclitaxel-based chemotherapy. Furthermore, none of the patients with beta-tubulin mutations had objective responses to taxanes [11]. In this study, we showed that there were no mutations of the beta-tubulin gene in gastric cancer. The difference may be that beta-tubulin mutations were specific to NSCLC, which may have been associated with NSCLC progression. Our results showed that, in gastric cancer, examination of beta-tubulin gene mutation might not be a useful predictor of resistance to paclitaxel-based neoadjuvant chemotherapy.

Dumontet et al. [14] have reported that beta-tubulin has intronless pseudogenes, which may be amplified by PCR with primer sets designed within exons. Kelley et al. [15] demonstrated that, in NSCLC, the primers used by Monzo [11] amplified a highly homologenous pseudogene (AF252825), which was located at 8p12, and primer sets newly designed by themselves did not amplify the pseudogene. Hasegawa et al. [16] also showed that, using breast-cancer tissues, primer sets designed in the sequence of exon 4 picked up the pseudogene, and the primer sets designed for nested PCR, using the outer PCR product amplified by the intronic primer set, did not amplify the pseudogene. Therefore, most of the mutations reported previously may be attributed to sequence differences between the beta-tubulin gene and pseudogenes.

Other molecules should be examined to predict the chemosensitivity of taxanes for gastric cancer. For example, there may be a need to elucidate the mechanism of cell death after damage to microtubules. Other studies have shown that overexpression of bcl- 2 or bclXL inhibits paclitaxel-induced apoptosis without affecting anti-microtubule function or cell-cycle blockage [17]. Raf/bcl-2 phosphorylation is thought to be a later

Table 3. Summary of results

\begin{tabular}{llcc}
\hline Position & $\begin{array}{c}\text { Nucleotide } \\
\text { change }\end{array}$ & $\begin{array}{c}\text { Genetic } \\
\text { variation }\end{array}$ & $\begin{array}{c}\text { Sample } \\
\text { number (\%) }\end{array}$ \\
\hline 85bp down stream of exon 1 & $\mathrm{G} \rightarrow \mathrm{T}$ & Intron & $20(40 \%)$ \\
32 bp down stream of exon 2 & $\mathrm{T} \rightarrow \mathrm{G}$ & Intron & $4(8 \%)$ \\
16bp down stream of exon 3 & $\mathrm{T} \rightarrow \mathrm{C}$ & Intron & $3(6 \%)$ \\
Codon 217 in exon 4 & $\mathrm{CTG} \rightarrow$ CTA & Silent & $9(18 \%)$ \\
Codon 303 in exon 4 & TGT $\rightarrow$ TGC & Silent & $9(18 \%)$ \\
\hline
\end{tabular}


step after damage to the microtubules [18]. Nishio et al. [19] suggested that inhibition of mitogen-activated protein (MAP) kinase and cdc2 kinase, caused by paclitaxel, enhanced the interaction between tubulin and microtubule-associated protein 2 .

In conclusion, examination of beta-tubulin gene mutations in gastric cancers cannot give sufficient information for the prediction of chemoresistance to taxanes. Further studies are needed to identify predictive molecules.

Acknowledgments This study was supported in part by a Grant-in-Aid from the Ministry of Education, Culture, and Science of Japan.

\section{References}

1. Yamaguchi K, Tada M, Horikoshi N, Otani T, Takiuchi H, Saitoh ST, et al. Phase study of paclitaxel with 3-h infusion in patients with advanced gastric cancer. Gastric Cancer 2002;5:90-5.

2. Ohtsu A, Boku N, Tamura F, Muro K, Shimada Y, Saigenji K, et al. An early phase II study of a 3-hour infusion of paclitaxel for advanced gastric cancer. Am J Clin Oncol 1998;21:416-19.

3. Parness J, Horwitz SB. Taxol binds to polymerized tubulin in vitro. J Cell Biol 1981;91:479-87.

4. Horwitz SB, Cohen D, Rao S. Taxol: mechanism of action and resistance. Monogr J Natl Cancer Inst 1993;5:55-61.

5. Milross CG, Mason KA, Hunter NR, Chung YK, Peters LJ, Milas L. Relationship of mitotic arrest and apoptosis to antitumor effect of paclitaxel. J Natl Cancer Inst 1996;88:1308-14.

6. Long BH, Fairchild CR. Paclitaxel inhibits progression of mitotic cell to $G$ phase by interference with spindle formation without affecting other microtubule functions during anaphase and telophase. Cancer Res 1994;54:4355-61.

7. Diaz JF, Andreu MJ. Assembly of purified GDP-tubulin into microtubule induced by taxol and taxotere: reversibility, ligand and stoichiometry, and competition. Biochemistry 1993;32:274755.

8. Rao S, Krauss NE, Heeding JM, Swindell CS, Ringel I, George $\mathrm{AO}$, et al. 3'-(p-azidobenzamido) Taxol photolabels the $\mathrm{N}$ terminal 31 amino acids of beta-tubulin. J Biol Chem 1994;269: 3132-4.

9. Schibler MT, Cabral F. Taxol-dependent mutants of Chinese hamster ovary cells with alterations in alpha- and beta-tubulin. $\mathbf{J}$ Cell Biol 1986;102:1522-31.

10. Ohta SK, Nishio N, Kubota T, Ohmori T, Funayama Y, Ohira T, et al. Characterization of a taxol-resistant human small-cell lung cancer cell line. Jpn J Cancer Res 1994;85:290-7.

11. Monzo M, Rafael R, Jose JS, Jin SL, Aurara O, Jose LGL, et al. Palitaxel resistance in non-small cell lung cancer associated with beta-tubulin gene mutations. J Clin Oncol 1999;17:1786-93.

12. Linse K, Mandelkow EM. The GTP-binding peptide of betatubulin. J Biol Chem 1988;263:15205-10.

13. Shivanna BD, Mejillano MR, Todd DW, Richard HH. Exhangeable GTP-binding site of beta-tubulin. J Biol Chem 1993:268:127-33.

14. Dumontet $\mathrm{CH}$, Duran GE, Stegar KA, Lindija BO, Branimir IS. Resistance mechanisms in human sarcoma mutants derived by single-step exposure to paclitaxel (taxol). Cancer Res 1996;56: 1091-7.

15. Kelley MJ, Li S, Harpole DH. Genetic analysis of the beta-tubulin gene, TUBB, in non-small-cell lung cancer. J Natl Cancer Inst 2001;93:1886-8.

16. Hasegawa S, Miyoshi Y, Egawa C, Ishitobi M, Tamaki Y, Monden $\mathrm{M}$, et al. Mutational analysis of the class I beta-tubulin gene in human breast cancer. Int J Cancer 2002;101:46-51.

17. Ibrad AM, Lin L, Bhalla K. Bcl-xL overexpression inhibits progression of molecular events leading to paclitaxel-induced apoptosis of human acute myeloid leukemia HL-60 cells. Cancer Res 1997;57:1109-15.

18. Blagosklonny MV, Giannakakou P, El-Deiry WS, Kingston DGI, Higgs PI, Neckers L, et al. Raf/bcl-2 phosphorylation: a step from microtubule damage to cell death. Cancer Res 1997;57:130-5.

19. Nishio K, Arioka H, Ishida T, Fukumoto H, Kurokawa H, Sata M, et al. Enhanced interaction between tubulin and microtubuleassociated protein 2 via inhibition of MAP kinase and cdc2 kinase by paclitaxel. Int J Cancer 1995;63:688-93. 